\title{
PROFIL DE PROFESOR : dr. ing. Radu ICHIM - 100 de ani de la naștere
}

\author{
I. Barbu, R.L. Cenușă
}

Barbu I., Ceunșă R., 2021. Professor's profile: Celebrating 100 years since the birth of dr. Radu Ichim Bucov. For. 21(1): 1-7.

Abstract. This year, on February 21, Romanian forestry celebrated a century since the birth of Professor Radu Ichim, the founder of the Norway spruce Research Station of Cîmpulung Moldovenesc. Being a paramount frontrunner of scientific research, Mr. Radu Ichim has shaped, by the power of his personal example, a worthwhile ethical and professional standard, which has challenged all of us. The authors of this editorial summarized the referential books published by Dr. Radu Ichim as well as his long and exceptional professional career.

Exceptional either by scope or high quality results, his long career was tied to Bucovina's forests, wherein he settled. He graduated the prestigious high-school Eudoxiu Hurmuzachi of Rădăuți, and the Forestry Faculty of Bucuresti, in 1944. In addition to the numerous research reports, articles and books, the most prevailing outcome of his prestigious career is the journal Bucovina Forestieră.

Keywords: Radu Ichim, professor, Bucovina, researcher, forests.

Author. Ion Barbu (ionbarbu51@gmail.com) - National Institute for Research and Development in Forestry "Marin Drăcea", Câmpulung Moldovenesc Station, Calea Bucovinei 73 bis, 725100 Câmpulung Moldovenesc, Radu Leontie Cenuşă - „Ștefan cel Mare” University of Suceava, Faculty of Forestry, 13 Universității, 720229 Suceava, Romania.

Manuscript received May 10, 2021; revised May 20, 2021; accepted May 20, 2021; online first May 21, 2021.

S-a împlinit, în luna februarie a anului 2021 un veac de la nașterea Profesorului Radu ICHIM - fondatorul Staţiunii Experimentale de Cultura Molidului din Câmpulngul Bucovinei. Totodată s-au scurs 24 de ani (28 martie 1997) de când paşii săi încetiniţi de greutatea vârstei şi glasul lui inconfundabil, dornic să rostească prea multe cuvinte dintr-o dată, au încetat să mai anime culoarele Staţiunii şi mai ales biroul său inimitabil, în care ne întâlneam adesea. Atunci s-a retras cu discreția-i caracteristică, creatorul de școală, profesorul şi cercetătorul, promotorul unei abordări complexe, pe baze ştiinţifice a gospodăririi pădurilor Bucovinei, puternic antropizate în ultimul secol.

Curgerea timpului constituie o bună ocazie de a-i rememora în chip de omagiu personalitatea sa complexă.

Prinşi noi, înşine în vâltoarea unor schimbări radicale am drămuit parcă, fără să vrem, momentul recunoştinţei.

Există însă şi o fecundă ipostază a scurgerii pe nesimţite a acestor intervale de timp, fie pentru aniversări, fie pentru omagieri. Deşi ameninţarea uitării pluteşte peste orice înfăptuire umană, în cazul de faţă, trecerea timpului 
a avut un efect contrar: a distilat până la detaliu raporturile dintre om şi operă, lăsându-i celei din urmă prilejul de a se susţine şi impune singură dincolo de subiectivismul inerent al coabitării cu creatorul ei. Faptul că astăzi majoritatea opiniilor sale sunt mai actuale ca oricând dovedeşte cu prisosinţă că examenul posterităţii a fost trecut. Că magistrul şi-a câştigat un loc al său, unic şi de necontestat în galeria silvicultorilor români.

Au trecut anii peste amintirea acestui pasionat cercetător al pădurilor Bucovinei. Pentru mulţi dintre tinerii şi mai puţin tinerii ingineri silvici, personalitatea Dr. ing. Radu ICHIM este puţin cunoscută. Rămân însă pentru totdeauna operele sale de sinteză referitoare la Istoria pădurilor şi silviculturii din Bucovina (1988), Gospodărirea rațională pe baze ecologice a pădurilor de molid (1990), Putregaiul roşu la molid. Măsuri de prevenire şi combatere (1993), Gospodărirea pe baze ecologice a vânatului în pădurile din zona montană (1994).

Născut la 21 februarie 1921 în comuna Horodnicul de Sus Jud. Rădăuţi (în prezent Suceava), într-o familie de intelectuali bucovineni a urmat primele 4 clase primare în comuna natală şi liceul teoretic „Eudoxiu Hurmuzachi” din Rădăuţi pe care 1-a terminat în primăvara anului 1939. In toamna anului 1939 a intrat prin concurs la Facultatea de Silvicultură de pe lângă Politehnica Bucureşti pe care a absolvit-o în 1944. Aici s-a bucurat de învăţătura unei pleiade de dascăli remarcabili, precum iluştrii profesori Marin Drăcea, V.N. Stinghe, D.A. Sburlan, Gr. Eliescu, C.D. Chiriţă ş.a. care la rândul lor au fost și sunt figurile luminoase ale științei silvice românești.

La data de 12 iunie 1945, după eliberarea din armată, a fost angajat ca inginer ataşat la Administraţia pădurilor Fondului bisericesc ortodox român din Bucovina al cărei bursier a fost în timpul facultăţii. In anul 1968 a susţinut teza de doctorat „Cercetări asupra preciziei metodelor de cubaj în raport cu variabilitatea formei arborilor in arboretele de molid" referenţi ştiinţifici fiind: prof. dr. Rucăreanu 2
Nicolae, prof. dr. Popescu I. Zeletin, dr. ing. Toma Gavril şi dr. ing. Giurgiu Victor.

După pensionare, în 1986, a continuat neîntrerupt activitatea redactând şi publicând diferite lucrări de istoriografie forestieră şi de gospodărire a pădurilor de molid din zona montană sub formă de analize şi sinteze abordate încă în anii anteriori.

Tot în această perioadă a reeditat revista „Bucovina forestieră” al cărei redactor responsabil a fost, publicaţie tehnico-ştiinţifică a forestierilor din Bucovina cu apariţie bianuală şi al cărei prim număr a apărut în anul 1993, reluându-se activitatea acesteia după o întrerupere de 50 ani.

Personalitate complexă, Dr. ing. Radu Ichim şi-a desfăşurat activitatea practic în toate domeniile de bază ale silviculturii româneşti. El a parcurs toate etapele formării profesionistului de mare valoare: proiectare, producţie-administraţie, învăţământ superior, cercetare ştiinţifică. Aceasta a constituit premisa faptului că întotdeauna a reuşit să fie în miezul problemelor ce au marcat silvicultura zonelor montane. În perioada 1946 - 1948 în calitate de inginer în centrala Fondului Bisericesc, la serviciul de amenajare a pădurilor, a amenajat pădurile din ocoalele silvice Mănăstirea Humorului, Frasin, Pojorâta, Solca și Iacobeni cu o suprafață de circa 42000 hectare. Această activitate avea să-și arate roadele imediate în elaboratele de amenajament, dar mai ales pe termen lung prin crearea unei imagini corecte și reale asupra stării și gospodăririi pădurilor acestei regiuni. Între anii 1958 - 1966 (după experiența învățământului superior), în calitatea sa de șef al Ocolului silvic Iacobeni a împădurit 2333 hectare, plantații integrale și completări. A produs peste 15 milioane de puieți în 11 pepiniere, a coordonat prelucrarea a circa 4000 de hectolitri de conuri în uscătoria ocolului silvic. A organizat marcarea şi punerea în valoare a peste 700 mii metri cubi de lemn (59 mii din rărituri, 432 mii produse accidentale, îndeosebi rupturi și doborâturi de vânt și zăpadă). În această perioadă şi-a constituit o echipă de colaboratori, un corp bine instruit, profesionalizat, cu 
o deosebită conștiință profesională care 1-au prețuit și stimat pentru tot timpul vieții. Ca realizări tranzitorii de la producție la cercetare, se menționează coordonarea proiectării şi construcției sediului Stațiunii experimentale de cultura molidului de la Câmpulung Moldovenesc, a celor două blocuri pentru locuințele cercetătorilor, montarea utilajelor complexe din import de la uscătoria de conuri Sadova.

Cercetarea ştiinţifică este domeniul în care Dr.ing. Radu Ichim a reuşit cele mai remarcabile realizări, fără de care silvicultura româ-

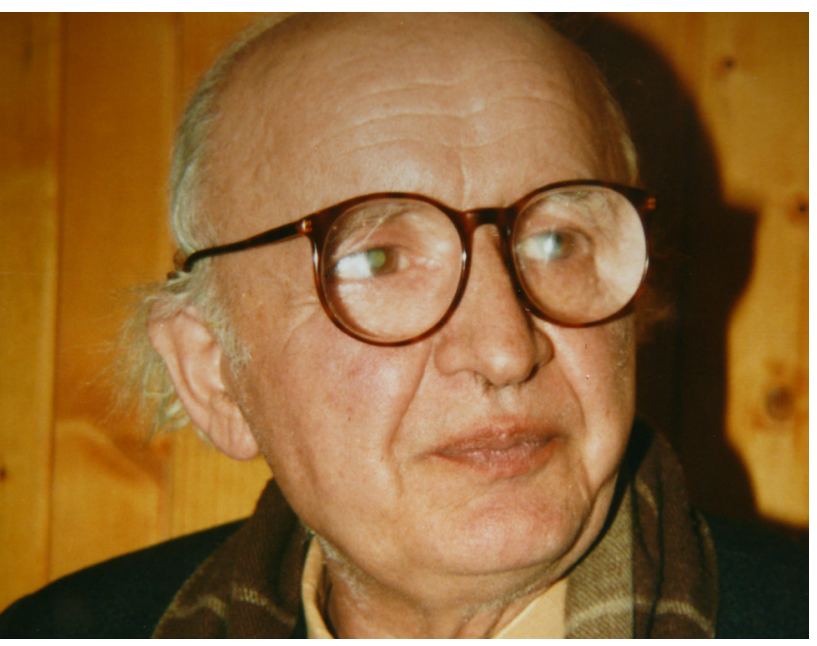
nească ar fi cu siguranță mai săracă. Desigur, că cea mai mare realizare a sa o constituie înfiinţarea Staţiunii experimentale de cultura molidului de la Câmpulung Moldovenesc al cărei fondator principal şi organizator a fost. Punerea în funcţiune a sediului Staţiunii în anul 1970 a dus aici la constituirea unui adevărat centru de cercetare în probleme de gospodărirea pădurilor de molid nu numai din această zonă ci şi pentru toată ţara. Staţiunea a devenit un adevărat Institut de cercetări ştiinţifice de nivel european, formarea şi pregătirea cadrelor de cercetare de aici, crearea de relaţii ştiinţifice, schimbul de publicaţii, vizite reciproce de documentare etc. contribuind la acest statut. Spre exemplificare, cu ocazia unei vizite în Bucovina în 1984 Dr.ing. Willy Kramer, şeful grupului IUFRO pentru silvicultura bradului arăta: „Staţiunea de cercetări silvice din Câmpulung Moldovenesc cu cercetătorii săi, este cel mai important for care face investigatii ştiințifice în pădurile din Bucovina".

Desigur, începuturile nu au fost uşoare, în anii 1968-1972 resimţindu-se acut lipsa de locuinţe pentru cercetători, problemă rezolvată după construirea celor două blocuri de locuinţe. Cine vizitează în prezent staţiunea nu-şi poate da seama că în urmă cu o jumătate de veac (53 de ani) pe acest teren era un ogor de cartofi. Treptat staţiunea s-a dezvoltat şi a luat un mare avânt astfel că de la un singur cercetă-

tor care exista în 1967, prin 1979 s-a ajuns ca aici să lucreze 14 cadre tinere de cercetare.

Un alt impediment de început a fost şi lipsa publicaţiilor de specialitate ca şi a informaţiilor din alte ţări. Schimbul de publicaţii era ca şi inexistent, iar activitatea cunoscută numai într-un cerc restrâns de specialişti. In câţiva ani echipa Dr.ing. Radu Ichim a reuşit să se facă cunoscută prin lucrările publicate, prin crearea legăturilor cu oameni de ştiinţă de mare prestigiu din ţările europene cele mai avansate şi cu tradiție în silvicultură.

Prestigiul acestei unităţi a crescut, devenind cunoscută nu numai în ţară ci şi peste hotare. Ca dovadă este faptul că la marele simpozion al molidului de la Augsburg, Germania din 1981 la care a participat ca invitat s-a evidențiat faptul că la Câmpulung Moldovenesc există singurul Institut de cercetare pentru molid din Europa, ca dovadă a importanţei care se arată acestui arbore în România. Cu această ocazie la Universitatea din Freiburg respectiv Institutul de silvicultură șeful stațiunii de la Câmpulung a prezentat în faţa studenţilor şi corpului profesoral o conferinţă despre cultura molidului în Carpaţi care a trezit un viu interes, dovadă fiind numeroase întrebări care i s-au pus.

Formarea şi pregătirea cadrelor de cercetare a fost o problemă care de la început a stat în atenţia sa. Pentru a nu deveni simpli culegători de date, cum era obiceiul până atunci, era ne- 
cesar ca în responsabilitatea staţiunii să treacă o serie de teme specifice pădurilor de molid. Pentru aceasta, a iniţiat şi condus un program special, ce viza problemele silviculturii molidului. Şi-a dat seama că, pentru pregătirea cadrelor, doctoratul este cea mai bună modalitate. Astfel între anii 1968-1992 s-au elaborat şi susţinut de cercetătorii de aici un număr de şapte teze de doctorat, ceea ce, pentru perioada respectivă, pentru o unitate exterioară a ICAS constituie o mare realizare. Ca regulă generală în buna pregătire a cadrelor, un accent s-a pus pe cunoaşterea limbilor străine de mare circulaţie, în special a celei germane. Importanţă deosebită s-a acordat şi utilizării calculului statistic, de mare necesitate în interpretarea datelor de cercetare. A căutat să imprime în mintea tuturor cercetătorilor ideea că fără aceste două probleme nu se poate face cercetare.

Pentru a facilita elaborarea tezelor de doctorat a căutat să coreleze pe cât posibil subiectul acestora cu unele teme de cercetare care se introduceau în planul tematic al staţiunii. Prin munca şi străduinţa depusă la Câmpulung Moldovenesc Dr. ing. Radu Ichim a reuşit ca într-o perioadă de 20 de ani să pună bazele unei adevărate şcoli de silvicultură românească cu specific bucovinean. Profesorul Dr.ing. Constantin D. Chiriță remarca : „,... consemnez cu preţuire aleasă şi multă admiraţie că Staţiunea de cultura molidului şi-a îndeplinit şi îndeplineşte în continuare, cu competenţă şi devotament rar întâlnit, misiunea ei înaltă de for luminos al ştiinţei în rezolvarea complexului impresionant de probleme grele privind existenţa, gospodărirea, reconstrucţia ecosistemică a pădurilor Bucovinei, în mare parte ale României”.

Lista lucrărilor publicate, reflectă foarte bine paleta largă a realizărilor, preocupărilor şi cercetărilor ştiinţifice pe care le-a abordat şi efectuat în cei 50 de ani de activitate 1945-1995 în slujba pădurilor din Bucovina. Această activitate a fost determinată la început de Cursul de Dendrometrie pe care-1 preda la Facultatea de Silvicultură din Câmpulung Moldovenesc şi, mai apoi, de la Braşov. Problema precizi4 ei metodelor de cubaj şi aceea a inventarierii prin sondaj a stat mereu în atenţia sa, până la susţinerea tezei de doctorat în 1968, respectiv la venirea la conducerea Staţiunii experimentale de cultura molidului. A efectuat primele cercetări din ţara noastră asupra inventarierilor parţiale cu suprafeţe de probă circulare îndeosebi şi asupra preciziei metodelor de cubaj şi a structurii arboretelor pe bază de măsurători executate în suprafeţe de probă tăiate ras. Ideea aceasta, a preciziei metodei de cubaj pe bază de măsurători efectuate în suprafeţe de probă tăiate ras 1-a obsedat încă de pe băncile facultăţii, de la orele de curs ale ilustrului sau profesor V.N. Stinghe. Odată cu începerea activităţii la Staţiunea experimentală de cultura molidului, şi-a reorientat cu totul activitatea de cercetare, spre latura ecolgică a ecosistemelor de molid, cercetările pe care le-a efectuat vizând în principal gospodărirea pădurilor de molid din această zonă. De un mare folos i-a fost în această privinţă practica şi experienţa din producţie, pe care a dobândit-o în intervalul de timp în care a condus Ocolul silvic Iacobeni (1957-1966) situat într-o zonă reprezentativă pentru pădurile de molid.

De la început, şi-a dat seama că problema centrală a acestor ecosisteme este de natură ecologică şi priveşte în principal stabilitatea lor, respectiv sporirea rezistenţei lor la perturbări de tot felul. Ca urmare, întreaga activitate pe care a desfăşurat-o în cercetarea ştiinţifică a fost axată îndeosebi pe problema stabilităţii ecosistemelor forestiere de molid din zona montană. Investigaţiile efectuate au pus în evidenţă faptul că factorii principali care afectează echilibrul ecologic al acestor păduri sunt vântul, vânatul (îndeosebi cervidele, ale căror efective au fost prea ridicate) şi putregaiul roşu de diferite tipuri (de rădăcină şi de rană). În plus, desigur şi omul, care prin metodele de gospodărire aplicate în aceste păduri în ultimul secol, cum ar fi tăierile rase pe mari suprafeţe şi crearea monoculturilor de molid a influențat esenţial echilibrul pădurilor. Pe baza investigațiilor efectuate s-au conceput, elaborat şi stabilit măsurile de gospodărire corespunză- 
toare, pe baze ecologice. In toate cercetările efectuate, Dr. ing. Radu Ichim a avut în vedere rezultatele finale, concretizate în recomandări tehnice pentru producţie. De aceea, în tot timpul în care a lucrat la Staţiunea experimentală de cultura molidului, a pus un accent deosebit pe introducerea în producţie a rezultatelor cercetărilor şi pe construirea de blocuri experimentale demonstrative în care s-au organizat instructaje, consfătuiri şi simpozioane cu personalul silvic de toate gradele nu numai din judeţul Suceava ci şi din alte zone ale ţării.

Problema calităţii producţiei de masă lemnoasă a stat tot timpul în atenţia sa şi a colaboratorilor săi. Cercetările aprofundate efectuate asupra extinderii şi intensităţii pe mari suprafeţe a daunelor provocate de vânt, zăpadă şi a putregaiului roşu de rădăcină, în raport cu unii factori staţionali şi de structură a arboretelor primele de acest gen realizate în ţara noastră - au dus la elucidarea multor aspecte ale stabilităţii ecologice ale acestor ecosisteme. Pentru a stabili influenţa structurii arboretelor şi unor factori staţionali asupra rezistenţei la rupturi şi doborâturi de vânt şi zăpadă, a conceput şi utilizat cu succes aşa-numitul indicator de stabilitate exprimat prin cantitatea de material lemnos calamitat $\left(\mathrm{m}^{3}\right)$ produs în unitatea de timp (anual) şi pe unitatea de suprafaţă (ha). Acest indicator s-a dovedit a fi foarte util în clasificarea respectiv cartarea arboretelor sub raportul rezistenţei la doborâturi de vânt şi rupturi de zăpadă.

Pentru prima dată în literatura noastră de specialitate (1964) a semnalat problema daunelor provocate de cerbi prin cojiri şi roaderi la arborii în picioare şi a efectuat şi publicat şi primele studii şi cercetări în această direcţie. Ulterior investigaţiile în acest sens s-au extins şi aprofundat, un accent deosebit punându-se pe influenţa acestor vătămări asupra calităţii lemnului la arborii atacaţi, respectiv pe apariţia putregaiului de rană. Legat de aceasta, a studiat şi analizat efectivele de vânat, densitatea acestora ca şi problema lupilor, în relaţie cu amploarea daunelor produse de cervide, rezultatele obţinute fiind de mare interes pentru gospodărirea acestor ecosisteme. Temele pe care le-a abordat constituie adevărate piese de referință pentru definirea unei silviculturi durabile:

- Determinarea influenței factorilor naturali și a modului de gospodărire asupra calităţii lemnului în arboretele de molid (1969 - 1974);

- Procedee de inventariere a doborâturilor de vânt în masă și pentru cubajul arborilor vătămați de vânt în județul Suceava (1971 - 1973);

- Cercetări asupra direcției, intensității și frecvenței doborâturilor de vânt în pădurile de răşinoase din județul Suceava (1972 - 1975);

- Stabilirea criteriilor de apreciere calitativă a arborilor de molid cu putregai intern pentru molidul din Moldova de nord (1976 - 1977);

- Cercetări privind măsurile de gospodărire a pădurilor de molid din nordul țării, cu fenomene de rupturi de zăpadă și doborâturi de vânt în vederea protecției mediului (1977 - 1980);

- Cercetări privind efectul rupturilor de zăpadă și vânt asupra rezistenței arboretelor de rășinoase la factori biotici și abiotici și elaborarea măsurilor de gospodărire ale acestora (1978 1980);

- Studiul complex de restabilire a echilibrului ecologic al pădurilor din nordul Moldovei (1978 - 1979);

- Ingrijirea și conducerea arboretelor de molid. Îndrumări tehnice (1985 - 1986).

Una din calităţile adevăratului cercetător este capacitatea de a comunica, talentul și generozitatea de a pune la dispoziția celor interesaţi din învățământ și din producție rezultatele muncii sale. Această dimensiune a fost strălucit întruchipată de persoana cercetătorului silvic, a autorului Radu Ichim. Lista lucrărilor publicate (peste 130) cuprinde lucrări de promovare silvică, recenzii, cursuri universitare, încununarea venind de la articolele de cercetare care au apărut în prestigioase reviste științifice.

Sintetizând, trebuie să evidențiem faptul că de numele profesorului și cercetătorului doctor inginer Radu Ichim se leagă realizări deosebite în cercetarea silvică românească fapt ce argumentează poziția de deschizător de drumuri în 
unele domenii precum:

- Primul curs universitar românesc de dendrometrie (500 pagini, litografiat) la Facultatea de silvicultură și exploatări forestiere de la Brașov;

- Inventarierea parțială (prin sondaje) a pădurilor;

- Variabilitatea structurală a caracteristicilor biometrice (îndeosebi a formei arborilor) la arborete de molid;

- Parametri biometrici ai putregaiului roșu la molid (forme, volum afectat, viteze de propagare);

- Semnalarea pentru prima dată în literatura noastră de specialitate (1964) a problemei daunelor produse prin cojiri şi roaderi și a efectelor pe termen lung asupra calității și stabilității arborilor;

- Impactul efectivelor ridicate de cervidee asupra răspândirii și propagării putregaiului la molid;

- Inventarierile statistice după un procedeu original pentru cartarea spațială a putregaiului roșu de rădăcină a molidului în pădurile județului Suceava;

- Fundamentarea unei metodologii proprii de analiză (factori staţionali și de arboret) și de cartare a vătămărilor produse de cervide;

- Determinarea preciziei metodelor de cubaj la molid;

- Primele cercetări extinse, cu caracter ecolo- gic asupra rupturilor și doborâturilor produse de vânt și zăpadă.

Dintre lucrările publicate în volum - între care „Gospodărirea raţională pe baze ecologice a pădurilor de molid" ( Ed. Ceres, 1990), „Putregaiul roşu la molid. Măsuri de prevenire şi combatere" (Ed. Ceres, 1993), „Gospodărirea pe baze ecologice a vânatului în pădurile din zona montană" (Ed. Ceres, 1994) - trebuie amintită „Istoria pădurilor şi silviculturii din Bucovina" (Ed. Ceres, 1988), realizare remarcabilă, care a avut la bază şi analiza vechilor amenajamente ale Fondului Bisericesc, elaborate cu peste un secol în urmă. In introducerea lucrării autorul motivează această apariţie: „Cunoaşterea trecutului acestor păduri şi a metodelor de gospodărire folosite prezintă interes nu numai pentru generaţia actuală de silvicultori, dar şi pentru cele care urmează. Să nu uităm faptul că silvicultori luminaţi au existat şi în trecut, că această ştiinţă şi artă totodată, care este silvicultura, nu s-a născut numai acum, sau odată cu noi"

Revista „Bucovina Forestieră” a constituit centrul de greutate al preocupărilor Dr. ing. Radu Ichim în perioada ce a urmat anului 1993, prin reînnodarea tradiţiilor activităţilor publicistice ale silvicultorilor din Bucovina. In calitate de redactor responsabil, a înţeles ca nimeni altul, necesitatea reluării apariţiei
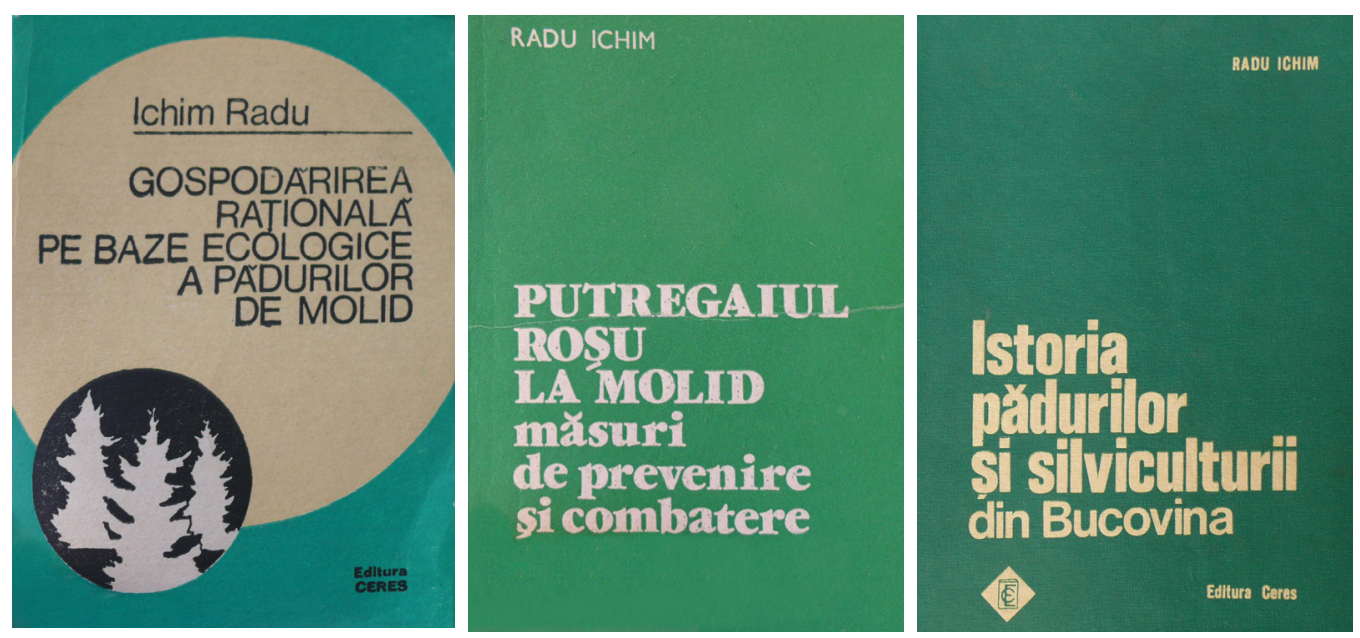
acestei reviste după o perioadă de 50 ani. In cuvântul introductiv intitulat „Către cititori” el prefigura viitoarele numere ale revistei : „Bucovina Forestieră va fi un cronicar fidel al vieţii pădurilor de aici, o punte de legătură între toţi slujitorii pădurilor din această zonă. Se vor populariza şi prezenta toate manifestările tehnico-ştiințifice organizate aici, tematica lor, obiectivele şi opiniile exprimate. Revista va prezenta analize şi sinteze ale diferitelor acte normative, probleme de legislaţie şi economie forestieră, care vor trebui comentate" Fiind un adept înfocat al continuităţii, al tradiţiei, al respectului pentru înaintași a ținut ca pe frontispiciul revistei să fie înserat moto-ul deja cunoscut: „Pădurea este altarul sfânt al lui Dumnezeu iar noi suntem preoții ei", preluat din revista „Codrii Bucovinei /1937.

Beneficiind de curajul şi entuziasmul anilor de tinereţe Dr. ing. Radu Ichim a avut o activitate de pionerat şi în cadrul învăţământului silvic superior în calitate de conferenţiar universitar, titular al cursurilor de vânătoare şi dendrometrie la Facultatea de silvicultură din Câmpulung Moldovenesc (1950 - 1953) şi al cursului de Dendrometrie de la Facultatea de Silvicultură din Braşov (1953 - 1957). Se remarcă apariţia primului Curs de Dendrometrie pe care 1-a redactat şi publicat (litografiat) în anul 1957, la Braşov, după care au învăţat mai multe serii de studenţi. De menţionat faptul ca o noutate pe atunci şi pentru prima dată în programa de învăţământ silvic superior a fost introducerea calculului statistic respectiv aplicaţiile acestuia la cunoaşterea structurii şi cubajului arboretelor. A condus şi îndrumat activitatea cercului ştiinţific studenţesc de pe lângă Catedra de Dendrometrie, a antrenat elevii de la Liceul Silvic din Câmpulung Moldovenesc la instalarea şi amplasarea de blocuri şi suprafeţe experimentale şi la efectuarea de măsurători biometrice în cadrul cercetărilor desfăşurate de Staţiunea experimentală de cultura molidului.

Un fapt demn de remarcat este acela că prin concepţia sa globală privind formarea cadrelor, prin îndrumarea cu profesionalism a tinerilor doctoranzi, Dr. ing. Radu Ichim nu a renunţat nici o clipă la preocupările sale didactice, manifestându-se ca un remarcabil profesor universitar modern care a ştiut să îndeplinească la cote înalte experienţa cu noile concepţii. Toţi cercetătorii formaţi la Câmpulung Moldovenesc îi datorează Domniei sale în primul rând realizarea lor ca profesionişti ai cercetării ştiinţifice silvice.

Nu se poate încheia acest articol omagial fără a se sublinia faptul că dacă revista „Bucovina forestieră" apare acum, aici și în această serie nouă se datorește în primul rând doctorului inginer Radu Ichim. Totodată, lucru mai puţin ştiut, el a pus umărul la relansarea în anul 1990 a învățământului silvic superior în Bucovina, a Facultății de Silvicultură de la Suceava.

Revista noastră are deosebit de onoranta ocazie de a-și aniversa fondatorul și totodată profesorul, cercetătorul, ctitorul și creatorul de școală care a fost Doctorul inginer RADU ICHIM. 